Copyright (C) 2020 University of Bucharest Printed in Romania. All rights reserved

ISSN print: $1224-5984$

ISSN online: 2248-3942
Rom Biotechnol Lett. 2020; 25(6): 2168-2173 doi: $10.25083 / \mathrm{rbl} / 25.6 / 2168.2173$

Received for publication, October, 6, 2018

Accepted, January, 29, 2019

Original paper

\title{
Silver nanoparticles inhibit $E$. coli virulence via down-regulation of fimH gene
}

\author{
SUMAYAH ABDULHUSSIEN IBRAHEEM ${ }^{1}$, AL-KELINE HAITHAM ALI KADHEM ${ }^{1}$, MAJID \\ SAKHI JABIR ${ }^{2}$, RUSUL AL KAHACHI ${ }^{3}$, GRATIELA GRADISTEANU PIRCALABIORU ${ }^{4,5}$, VLAD \\ BUDU $^{6,7}$, IRINA GHEORGHE ${ }^{4,5, *}$, IONELA ALEXANDRU ${ }^{4,5^{*}}$, DAN MIHAILESCU ${ }^{1}$
}

${ }^{1}$ University of Bucharest, Faculty of Biology, Department of Animal Physiology and Biophysics, Splaiul Independenței Street, no. 91-95, sector 5, 050095, Bucharest, Romania

${ }^{2}$ Department of Applied science, University of Technology, Baghdad, Iraq

${ }^{3}$ Department of Biology, University of Turku, Finland

${ }^{4}$ Department of Microbiology, Faculty of Biology, University of Bucharest, Romania

${ }^{5}$ Research Institute of the University of Bucharest, Bucharest, Romania

6“"Carol Davila" University of Medicine and Pharmacy, B-dul Eroilor Sanitari 8, 050474, Bucharest, Romania

${ }^{7}$ Institute of Phonoaudiology and Functional ENT Surgery "Prof. Dr. D. Hociotă", Bucharest, Romania

\begin{abstract}
Nowadays, nanoparticles are employed in a vast number of downstream biological approaches including drug delivery,imaging of tumors and antimicrobial therapy. Silver nanoparticles (Ag NPs) are one of the most common type of nanoparticles used in medical applications. This study aimed to identify the mechanism of action exhibited by AgNPs against $E$. coli bacterial strains. The antibacterial activity of Ag NPs was tested using the agar well diffusion assay ands their mode of action was investigated by AO-EtBr staining and scanning electron microscopy. Moreover, the effect of AgNPs nanoparticles on E. coli fimH gene was carried out using qRT-PCR. Ag NPs exhibited antimicrobial activity against uropathogenic E. coli strains. We show here that Ag NPS acted on the cytoplasmic membrane and nucleic acid of bacteria resulting in a loss of integrity and increased permeability, nucleic acid damage, and down-regulated expression of the fim $H$ gene.
\end{abstract}

Keywords Silver nanoparticles, E. coli, Antimicrobial activity, fimH gene.

To cite this article: IBRAHEEM SAH, ALI KADHEM ALH, JABIR MS, RUSUL AL KAHACHI, PIRCALABIORU GG, BUDU V, GHEORGHE I, ALEXANDRU I, MIHAILESCU D. Silver nanoparticles inhibit $E$. coli virulence via down-regulation of fimH gene. Rom Biotechnol Lett. 2020; 25(6): 2168-2173. DOI: 10.25083/rbl/25.6/2168.2173

$\triangle$ *Corresponding author: IRINA GHEORGHE and IONELA ALEXANDRU, Faculty of Biology - University of Bucharest, 1-3 Ale. Portocalelor, Bucharest, 60101, Romania

E-mail: IRYNA 84@yahoo.com ionela.alexandru@lpiancului.ro 


\section{Introduction}

Nanotechnology has introduced a great scientific advancement in the field of research and technology, especially due to its various medical applications (SALATA [1]). These include several applications in biomedicine, especially in pathology treatment and diagnosis (NEACSU [2], WANG [3]).

Nowadays, increased antibiotic resistance prevalence among bacteria is one of the greatest challenges to human health. Moreover, the poor stability, solubility, and side effects that collectively cause inefficiency of the current antibacterial therapy lead to the development of new antimicrobial strategies. In line with this, nanoparticles gained considerable attention due to their physicochemical properties, biodistribution, enhanced uptake, and drug targeting efficiency (PENESYAN et al [4]; FAIR \& TOR [5]). The quick development of nanotechnology in recent years has created a wide array of engineered nano-particles or materials, including silver nanoparticles (ZHANG \& al [6]). Silver nanoparticles have gained interest due to their precise properties (e.g., diameter,shape, physical and chemical properties) which may be integrated into antimicrobial applications, biosensors, composite fibers (CALDERÓNJIMÉNEZ et al [ 7]; OZIN [8]) medical devices coatings, optical sensors, cosmetics, diagnostics, or drug delivery systems (AHAMED et al [9]; MARASSI et al [10], ZUBERBIER \& al [11]).

Amongst numerous artificial techniques for AgNPs synthesis, biological techniques appear to be easy, speedy, non-toxic, reliable (HABEEB [12]). NP surface, size, length distribution, morphology, composition, capping, agglomeration, and dissolution rate are a critical factor for avoiding cytotoxicity. In an effort to satisfy the requirements of AgNPs, numerous techniques were followed for synthesis. Typically, traditional physical and chemical strategies appear to be very costly and unsafe. The antibacterial activity of Ag NPs is due to their small size and large surface area to volume ratio [DAS et al [13] which allows them to enter the micrbial cells subsequently causing damage to the cell membrane (RAMALINGAM et al [14]).

The aim of this study was the characterization of AgNPs in terms of their antimicrobial activity against uropathogenic E. coli strains (UPEC) since UPEC strains are the most numerous pathogens that represent $85 \%$ of community and $50 \%$ of hospital acquired UTIs (GOMES et al [15]; HOJATI et al [16]).

\section{Material and Methods}

\section{Bacterial isolates}

Twelve Escherichia coli strains were isolated from with UTI. For the isolation of UTI causing strains, mid-stream urine sample was taken for each patient in sterilized test tubes and transported to the laboratory for microbiological analysis. The strain isolation was made on
MacConkey Agar which is considered a selective medium for the isolation, purification and identification of E. coli. The isolates were examined for their shape and color. All plates were incubated at $37^{\circ} \mathrm{C}$ for $18-24$ hours to identify the bacterial types (MURRAYet al [17]). The identification of the isolates was performed using the VITEK II automatic analyzer (BioMerieux).

\section{Characterizations of AgNPs}

\subsection{Transmission microscopy technique (TEM)}

TEM analysis was carried out to visualize the morphology and the size of NPs. Thin films of the sample were prepared on a cover slide grid, the cover slide was allowed to dry at room temperature and they were further analysed (PATRA \& BAEK [18]).

\subsection{Dynamic light scattering}

Detection of light scattering from matter is a useful method with applications in several clinical disciplines wherein, relying on the light supply and detector, unique properties of molecules may be studied. Samples were sonicated for 5 mins and the length distributions of the nanoparticles was investigated through the DLS method using an dapated protocol from (ZHU \& al [19]).

\section{The AgNPs activity on $E$. coli}

\subsection{Antimicrobial activity of AgNPs}

Antimicrobial activity of AgNPs against E. coli strains was analyzed on Mueller Hinton (MH) agar plates using a disk diffusion method. Fresh bacterial strains were adjusted to a density corresponding to 0.5 McFarland (OWUAMA [20]). For this purpose, $5 \mu \mathrm{L}$ from a stock solution of the tested product, containing different concentrations of NPs $(25,50,75$, and $100 \mu \mathrm{g} / \mathrm{ml})$, as well as the control used at the same concentration, were distributed on a blank paper disk. Dimethyl sulfoxide (DMSO) was used as solvent and was comparatively tested for its potential antimicrobial activity. All the experiments were performed in triplicate. The plates were incubated for $24 \mathrm{~h}$ at $37^{\circ} \mathrm{C}$. The antimicrobial activity was quantified by measuring the bacterial growth inhibition zones around the spots (YANG et al [21]; BROWN \& PRESCOTT [22]).

To measure the effect of AgNPS in bacterial growth curve, E. coli was cultured at $37^{\circ} \mathrm{C}$ on Muller-Hinton agar plates and inoculations were given from the fresh plates in to $50 \mathrm{ml}$ of nutrient broth culture medium. The bacterial growth was allowed until an $\mathrm{OD}_{600 \mathrm{~nm}}$ of 0.1 was reached since this represents $10^{8} \mathrm{CFU} / \mathrm{ml}$. Then, $1 \mathrm{ml}$ of $E$. coli was added to $50 \mathrm{ml}$ of nutrient broth supplemented with AgNPs at a concentration $50 \mu \mathrm{g} / \mathrm{ml}$ and the flasks were incubated at $37^{\circ} \mathrm{C}$ for $24 \mathrm{~h}$ with shaking. The bacterial growth was determined by measuring optical density every 6 hours using a spectrophotometer.

The antimicrobial activity of AgNPs was also evaluated by fluorescence microscopy.

In order to detect the impact of the AgNPs on the viability of $E$. coli cells were stained with Acridine 
orange / Ethidium Bromide (AO/EtBr). For this, $20 \mu \mathrm{l}$ of bacterial suspension and $5 \mu \mathrm{l}$ of $\mathrm{AO} / \mathrm{EtBr}$ were incubated for 10 minutes and then the sample were centrifuged $15 \mathrm{~min}$ at 1500 r.p.m and washed with PBS three times. After that, $5 \mu$ of each sample were plated on a slide and were analyzed by fluorescence microscopy (JABIR et al [23]).

\subsection{Effect of AgNPs on expression of fimH gene}

Quantitative Real-Time PCR (RT-PCR) was used to evaluate the effect of AgNPs on E-coli fimH gene expression. The primers used for amplification of the fimH gene were F:5'-CTGATGGGCTGGTCGGTAAAT-3', R:5'-GTG CAT GCA CAT TCC CTG CAG TCA-3'. RNA was extracted from $E$. coli using a commercial purification system (Abcam ExCellenCT Lysis Kit). The RNA concentrations ranged between 40 and $50 \mathrm{ng} / \mu \mathrm{l}$. The 16S rRNA gene was used as housekeeping gene. Detection of gene expression was performed using Abm's One-Step BrightGreen qRT-PCR Kit (CHABOU et al [24]).

\subsection{Statistical analysis}

The obtained data were statically analyzed using unpaired T-test with GraphPad Prism 6. The values were presented as the Mean \pm S.E of the three replicate of each experiments (JABIR \& al [ 25]).

\section{Results and Conclusion}

\section{Characterization of AgNPs by TEM}

TEM analysis was used to verify the physical (diameter, dispersion, morphology) parameters of the nanostructures. As seen in Figure 1, AgNPs exhibited a colloidal morphology as targeted via the selection of the relative quantity fractions inside the synthesis of the constituent blocks within the diblock copolymer and had a particularly slim size distribution with diameters of 23 and $30 \mathrm{~nm}$ (Fig. 1A).

\section{Characterization of AgNPs by DLS}

DLS technique is used to verify Brownian motion of spherical dispersed particles and to relate this to the hydrodynamic length of the particles dispersed within the solution via dynamic fluctuations of scattered light intensity. This scattered light intensity is mathematically manipulated to relate the hydrodynamic length of the debris. A vital characteristic of Brownian motion measured with the aid of DLS is that small debris circulates quicker in the assessment of large debris, and the relationship between the dimensions of a particle and its velocity due to Brownian motion is defined within the Stokes-Einstein equation as visualized in (Fig. 1B), the AgNPs diameter was within the range of $20-30 \mathrm{~nm}$.
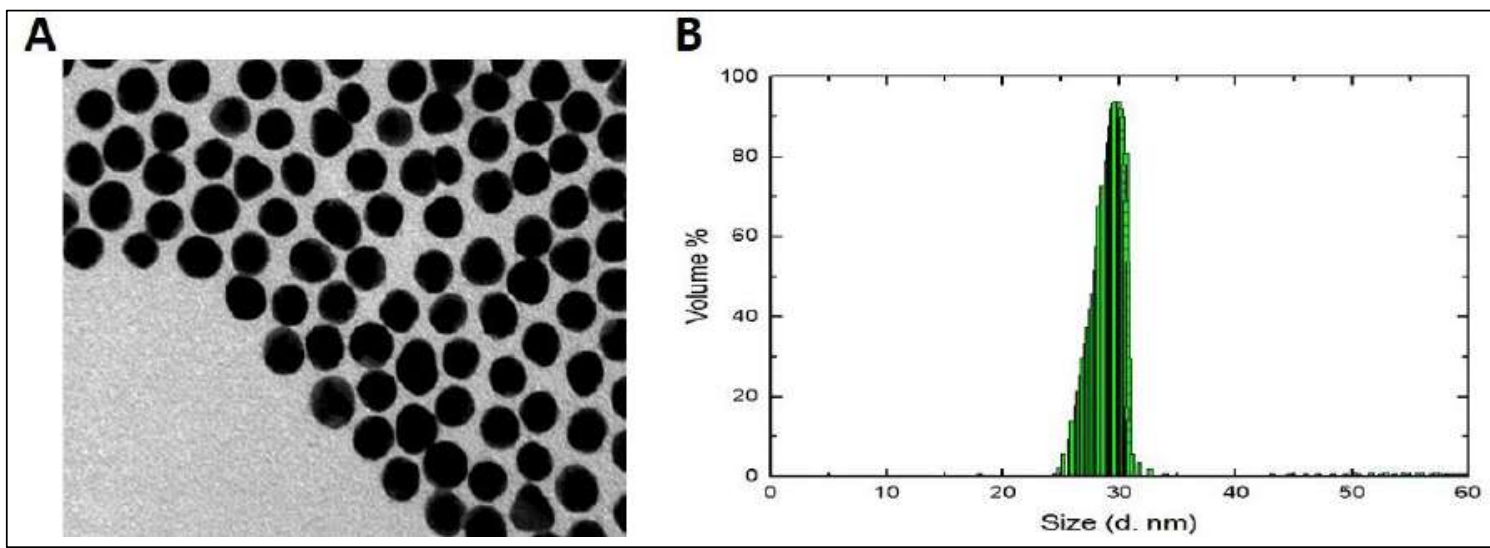

Figure 1. Morphological analysis (A-TEM, B-DLs) for AgNPs.

\section{Antimicrobial activity of AgNPs}

AgNPs harbored antimicrobial activity against E. coli as sown in Figure 2. E. coli growth was gradually inhibited as the AgNPs concentration increased. At a concentration of $25 \mu \mathrm{g} / \mathrm{ml}$, the growth inhibition zone had a diameter of $14 \mathrm{~mm}$ while for $50 \mu \mathrm{g} / \mathrm{ml}$, the inhibition zone was $20 \mathrm{~mm}$. The inhibition zone had a $23 \mathrm{~mm}$ diameters in case of AgNPs with a $75 \mu \mathrm{g} / \mathrm{ml}$ whereas for $100 \mu \mathrm{g} / \mathrm{ml}$, the inhibition zone diameter was $30 \mathrm{~mm}$. The bacterial growth rate was measured spectophotomectrically at $600 \mathrm{~nm}$ at regular intervals as the increase in bacterial multiplication would increase the OD values and this could reflect the inhibitory efficacy of AgNPs.

To study the antibacterial activity of AgNPs, E. coli was inoculated in nutrient broth in the presence and absence of nanoparticles at a concentration of $50 \mu \mathrm{g} / \mathrm{ml}$. There was a clear inhibitory action of AgNPs, especially after 6, 12, 18 , and 24 hours of treatmen. The inhibitory effect of AgNPs was measured and the statistical analysis has been shown in Figure (2B).

Based on our results we can confirm the role of AgNPs in inhibiting the growth of E. coli strains and we can suggest that AgNPs can be a new generation of antimicrobial agents which could be effective against multidrug resistant microorganisms. The antimicrobial resistance of microorganisms can be linked to the presence of the outer membrane. The outer membrane is able to make the small molecule penetrate into the cell while molecules with large molecular mass can't penetrate (CHATTOPADHYAY \& JAGANNADHAM [26]). Consequently, the use of AgNPs should enhance their activity due to their ability to penetrate via the cell membrane (SINGH et al [27]). 


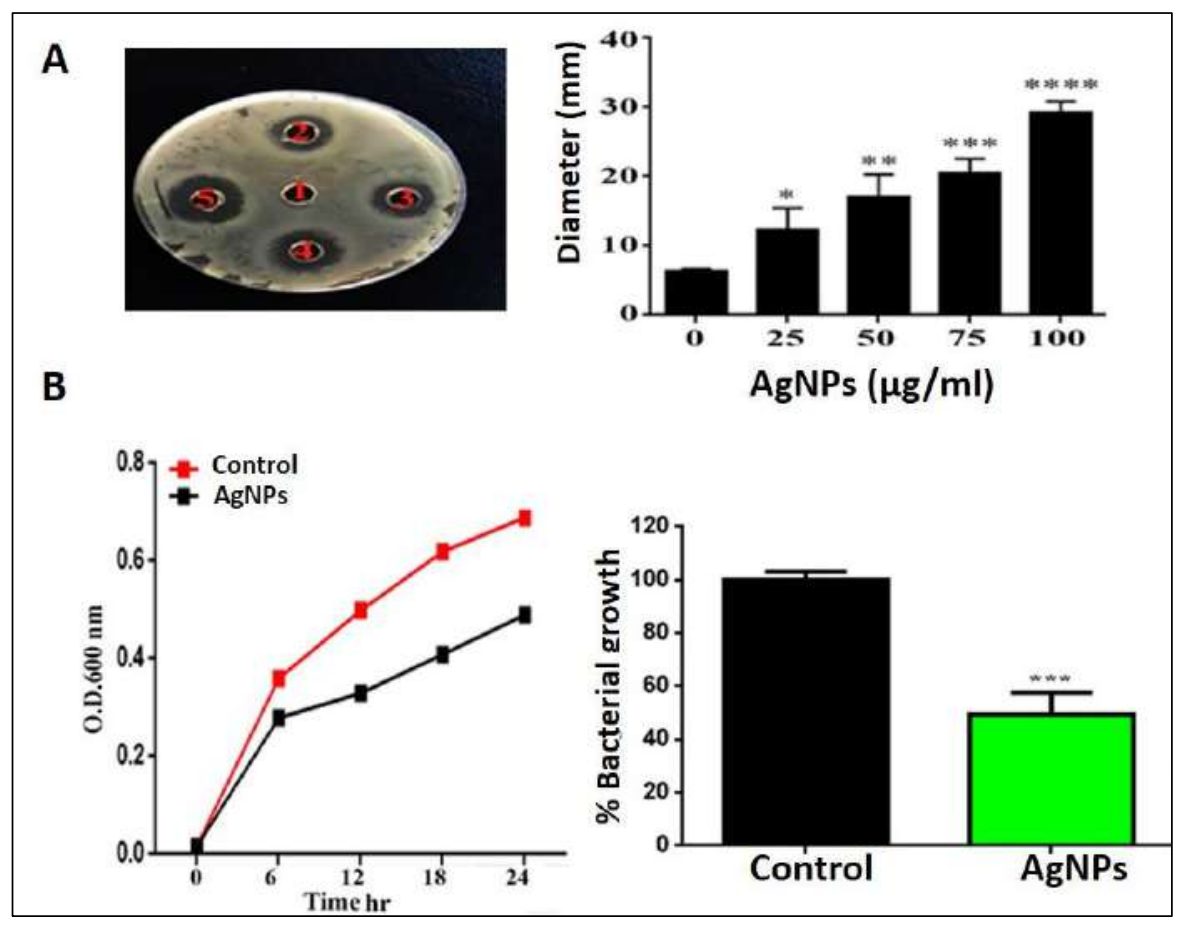

Figure. 2. Antimicrobial activity of AgNPs against E. coli. A. 0- negative control, 1- AgNPs concentration $25 \mu \mathrm{g} / \mathrm{ml}, 2$ - AgNPs concentration $50 \mu \mathrm{g} / \mathrm{ml}, 3-$ AgNPs concentration $75 \mu \mathrm{g} / \mathrm{ml}$, 4- AgNPs concentration $100 \mu \mathrm{g} / \mathrm{ml}$. The values are shown as the mean \pm SD $* p<0.05, * * p<0.01, * * * p<0.001$. B. Effect of AgNPs in inhibiting the growth rate of $E$. coli. The values are shown as mean \pm SD. $* * * p<0.001$.

\section{Bacterial morphology upon exposure to AgNPs}

Scanning electron microscope had been used to investigate the efficiency of Silver nanoparticles at concentration $50 \mu \mathrm{g} / \mathrm{ml}$ on cellular morphologies of E. coli. SEM results visualized the differences between the bacterial strain which is treated with Silver nanoparticles and non-treated bacterial isolate. SEM images display that E. coli had rod shape colonies \& Silver nanoparticle effect on the membrane of bacteria and make it more permeable and rupture as shown in Figure 3A. Previous studies have shown that expousure of bacterial strains to AgNPs can produce structural changes in outer cell membrane leading to cell death (SONDI \& SALOPEKSONDI [28]; RAMALINGAM et al [14]). This disrupting is due to the increasing of osmotic balance that make bacterial cell more leakage to cellular molecules outside the cell. Bacterial cell wall or peptidoglycans across related mesh that offers a cell its form strength and osmotic balance (COHEN [29]).

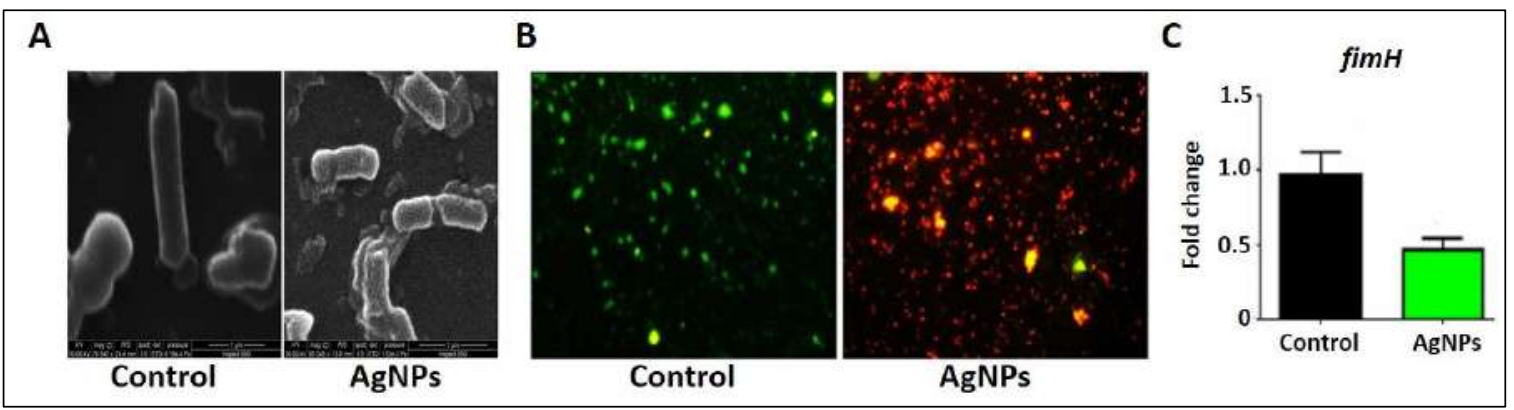

Figure. 3. The effect of AgNPs on E-coli morphology, viability and virulence. A. Visualization of E-coli treated with AgNPs using SEM, treated bacterial cells showing membrane damage. B. Fluorescence microscopic images of the green/red fluorescence stained E-coli in the absence/presence of AgNPs. C. Influence of AgNPs on fimH gene expression. The value is shown as the mean \pm SD.

\section{AO/EtBr dual staining}

The impact of AgNPs on the viability of E. coli was studied using an $\mathrm{AO} / \mathrm{EtBr}$ stain. While AO stains both viable and non-viable cells, EtBr binds to nucleic acids and permeates only the cells which lost membrane integrity. The results from the dual staining suggested that AgNPs harbor high capacity to target the cell wall membrane of bacterial strains, since most of the cell exhibited a red color due to membrane integrity loss as shown in Figure 2B. There are studies reporting that AgNPs 
may interact in a manner with their target proteins that leads to DNA damage due to the inhibition of the ligase domain of topoisomerase, while the nuclease domains are left intact, thereby, allowing the enzyme to cleave DNA without re-ligation (SINGHNEENU et al [30]; PIZARROCERDÁ \& COSSART [31]). Numerous antimicrobials result in metabolic perturbations, downstream of the interaction with their respective cellular targets (YANG et al [21]), VIZCARRA \& al [32]). Proteomic analyses suggest that the antimicrobial activity of AgNPs is due to their effect on membrane proteins and the induced oxidative stress (ZHANG, GÖKCE \& al [33]). This study proposes possible mechanisms underlying AgNPs-induced cytotoxicity in bacterial cells. Mainly, AgNPs induce oxidative stress, causing instability in the cell membrane and making the membrane more permeable by incorporating AgNPs. This incorporation leads to the formation of pits on the membrane that are permeable, leading to a cellular osmotic breakdown, thus, releasing the intracellular content.

\section{Effect of AgNPs on expression of fimH gene}

The mechanisms behind the antimicrobial activity of AgNPs was assayed through E.coli fimH mRNA determination via qRT-PCR, using $16 \mathrm{~S}$ rRNA gene as control gene. As seen in Figure (3c), E. coli strains treated with AgNPs exhibited a downregulated fimH expression.

Previous studies have indicated that the attachment to the urothelial cell surface is mediated by FimH adhesion, placed at the tip of the type 1 fimbriae, which provides the prevention of bacterial washout by urine flow and begins bacterial invasion (SU [34]); FINER \& LANDAU [35]). The fimH gene is a major type fimbriae for adherence due to the presence of high tropism of urinary tract receptors and it contains mannose binding pockets that recognize mannose containing glycoprotein receptors present on the host cell surface (HOJATI et al [16]). (TCHESNOKOVA $\&$ al [36]). In case of UTI, the apical surface of urinary bladders bears integral membrane uroplakin 1a that acts as a main receptor for fimH. It was revealed that the enhanced pathogenicity of $E$. coli can result in the high binding capacity of FimH, hence FimH may be employed as a possible vaccine candidate and/or diagnostic marker. Another study by (WATTS et al [37]) has shown that the fimH gene was the most common virulence gene and was discovered in $98 \%$ of $E$. coli strains isolated from patients with UTIs. These results confirm the role of the antibacterial activity of AgNPs in reducing the risk of disease (UTIs) that is in among the most common infectious disease for humans caused by $E$. coli and highlight the potential use of AgNPs as a new antibacterial agents instead of traditional antibiotics.

\section{Conclusion}

The advent of nanotechnology has significantly improved different fields of human activity, including pharmaceutical and biomedical applications. Nanoparticles are constantly reported to harbor potent antimicrobial activity against a wide array of pathogens (NEACSU \& al [2], IBRAHEEM et al [40], JABERI et al [39]).
E. coli is a versatile, well-set pathogen with the potential to advance and adapt to its host as well as to the treatments changed to control its invasive damage. New antibacterial agents are required. In light of this, AgNPs are potentially effective for inhibiting the growth and virulence of this important pathogen.

\section{Acknowledgments}

The financial support of the research grant for young researchers PN-III-P1.1-PD-2016-1798, granted by the Executive Unit forFinancing Higher Education, Research, Development and Innovation (UEFISCDI) are gratefully acknowledged.

\section{References}

1. SALATA OV. Applications of nanoparticles in biology and medicine. Journal of Nanobiotechnology, 2(1): 3 (2004).

2. NEACSU IA, MELENTE AE, HOLBAN AM et al. Novel hydrogels based on collagen and $\mathrm{ZnO}$ nanoparticles with antibacterial activity for improved wound dressings. Rom Biotechnol Lett. 2019; 24(2): 317-323. DOI: 10.25083/ $\mathrm{rbl} / 24.2 / 317.323$

3. WANG EC, WANG AZ. Nanoparticles and their applications in cell and molecular biology. Integrative Biology, 6(1): 9-26, (2014).

4. PENESYAN ANAHIT, GILLINGS MICHAEL, PAULSEN IAN T. Antibiotic discovery: combatting bacterial resistance in cells and in biofilm communities. Molecules, 20(4): 5286-5298 (2015).

5. FAIR RJ \& TOR Y. Antibiotics and bacterial resistance in the $21^{\text {st }}$ century. Perspectives in medicinal chemistry, 6: PMC. S14459 (2014).

6. ZHANG XF, LIU ZG, SHEN W, GURUNATHAN S. Silver nanoparticles: synthesis, characterization, properties, applications and therapeutic approaches. International journal of molecular sciences, 17 (9): 1534 (2016).

7. CALDERÓN-JIMÉNEZ B, JOHNSON ME, MONTORO BUSTOS AR, MURPHY KE, WINCHESTER MR, VEGA BAUDRIT JR. Silver nanoparticles: technological advances, societal impacts, and meteorological challenges. Frontiers in chemistry, 5:6 (2017).

8. OZIN GA. Nanochemistry Views, University of Toronto (2014).

9. AHAMED M, MOHAMAD S ALSALHI, MKJ SIDDIQUI. Silver nanoparticle applications and human health. Clinica chimica Acta, 411 (23): 1841-1848 (2010).

10. MARASSI V, DI CRISTO L, SMITH SGJ, ORTELLI S, BLOSI M, COSTA AL, RESCHIGLIAN P, VOLKOV Y, PRINA-MELLO A. Silver nanoparticles as a medical device in healthcare settings: a five-step approach for candidate screening of coating agents. Royal Society open science, 5(1): 171113 (2018).

11. ZUBERBIER T, ABERER W, ASERO R, BINDSLEVJENSEN C, BRZOZA Z, CANONICA GW, et al. The EAACI/GA2LEN/EDF/WAO Guideline for the definition, classification, diagnosis, and management of urticaria: the 2013 revision and update. Allergy, 69 (7): 868-887 (2014).

12. MARIO KHALIL HABEEB. Biosynthesis of nanoparticles by microorganisms and their applications. 
International Journal of Advanced Scientific and Technical Research, 1(3):4 -51 (2013).

13. DAS VIDHYA LAKSHMI, THOMAS ROSHMI, VARGHESE RINTU T, SONIYA EV, MATHEW JYOTHIS, RADHAKRISHNAN EK. Extracellular synthesis of silver nanoparticles by the Bacillus strain CS 11 isolated from industrialized area. 3 Biotech, 4(2): 121-126 (2014).

14. RAMALINGAM BASKARAN, PARANDHAMAN THANUSU, DAS SUJOY K. Antibacterial effects of biosynthesized silver nanoparticles on surface ultrastructure and nonmechanical properties of gram-negative bacteria viz. Escherichia coli and Pseudomonas aeruginosa. ACS applied materials \& interfaces, 8(7): 49634976 (2016).

15. TÂNIA AT GOMES, WALDIR P ELIAS, ISABEL CA SCALETSKY, BEATRIZ EC GUTH, JULIANA F RODRIGUES, ROXANE MF PIAZZA, LUÍS CS FERREIRA, MARINA B MARTINEZD. Diarrheagenic Escherichia coli. brazilian journal of microbiology, 47: 3-30 (2016).

16. HOJATI ZOHREH, ZAMANZAD BEHNAM, HASHEMZADEH MORTEZA, MOLAIE RAZIEH, GHOLIPOUR ABOLFAZL. The FimH gene in uropathogenic Escherichia coli strains isolated from patients with urinary tract infection. Jundishapur journal of microbiology, 8(2) (2015).

17. PATRICK R. MURRAY, KEN S ROSENTHAL, MICHAEL A PFALLER. Medical microbiology, Elsevier Health Sciences (2015).

18. PATRA JK, K-H BAEK. Green Nanobiotechnology: factors affecting synthesis and characterization techniques. Journal of Nanomaterials 2014: 219 (2014).

19. SHAOBIN ZHU, LING MA, SHUO WANG, CHAOXIANG CHEN, WENQIANG ZHANG, LINGLING YANG, WEI HANG, JOHN P. NOLAN, LINA WU and XIAOMEI YAN. Light-scattering detection below the level of single fluorescent molecules for high resolution characterization of functional nanoparticles. ACS Nano, 8 (10): 10998-11006 (2014).

20. OWUAMA CI. Determination of minimum inhibitory concentration (MIC) and minimum bactericidal concentration (MBC) using a novel dilution tube method. African Journal of Microbiology Research, 11(23): 977-980 (2017).

21. XIAO-NANYANG, IMRAN KHAN, SUN CHULKANG. Chemical composition, mechanism of antibacterial action and antioxidant activity of leaf essential oil of Forsythia koreana deciduous shrub. Asian Pacific journal of tropical medicine, 8 (9): 694-700 (2015).

22. BROWN HELEN, PRESCOTT ROBIN. Applied mixed models in medicine. John Wiley \& Sons. Ltd (2014).

23. JABIR MS1, TAHA A ALI, SAHIB UI. Linalool loaded on glutathione-modified gold nanoparticles: a drug delivery system for a successful antimicrobial therapy. Artificial cells, nanomedicine, and biotechnology, 1-11 (2018).

24. S. CHABOU, T. LEANGAPICHART, L. OKDAH, S. LE PAGE, L. HADJADJ, J.-M. ROLAIN. Real-time quantitative PCR assay with Taqman probe for rapid detection of MCR-1 plasmid-mediated colistin resistance. New Microbes and New Infections, (13): 71-74 (2016).
25. JABIR MAJID S, SULAIMAN GHASSAN M, TAQI ZAINAB J, LI DONG. Iraqi propolis increases degradation of IL-1 $\beta$ and NLRC4 by autophagy following Pseudomonas aeruginosa infection. Microbes and infection, 20(2), (2018).

26. CHATTOPADHYAY MK, JAGANNADHAM MV. Vesicles-mediated resistance to antibiotics in bacteria. Frontiers in microbiology, 6: 758 (2015).

27. SINGH RAJNI, SMITHA MS, SINGH SURINDER P. The role of nanotechnology in combating multi-drug resistant bacteria. Journal of Nanoscience and nanotechnology, 14(7): 4745-4756 (2014).

28. IVAN SONDI, BRANKA SALOPEK-SONDI. Silver nanoparticles as antimicrobial agent: a case study on E. coli as a model for Gram-negative bacteria, Journal of Colloid and Interface Science (275): 177-182 (2004).

29. COHEN BE. Functional linkage between genes that regulate osmotic stress responses and multidrug resistance transporters: challenges and opportunities for antibiotic discovery. Antimicrobial agents and chemotherapy, 58(2): 640-646 (2014).

30. SINGH NEENU, BELLA MANSHIAN, GARETH J.S. JENKINS et al. NanoGenotoxicology: the DNA damaging potential of engineered nanomaterials. Biomaterials, 30 (23-24): 3891-3914 (2009).

31. JAVIERPIZARRO-CERDÁ, PASCALE COSSART. Cell, 124(4):649-864 (2006).

32. VIZCARRA GO, CASAGRANDE M, NIMBALKAR SS. Modeling Behaviour of Railway Ballast in Prismoidal Apparatus Using Discrete Element Method, 143:11771184 (2016).

33. ZHANG D, GÖKCE B, BARCIKOWSKI S. Laser Synthesis and Processing of Colloids: Fundamentals and Applications. Chem Rev, 8; 117(5): 3990-4103 (2017).

34. CHUNG-JEN SU. Female lower urinary tract infection. JTUA, 19:12-20 (2008).

35. GALFINER, DANIEL LANDAU. Pathogenesis of urinary tract infections with normal female anatomy. The Lancet infectious disease, 4(10): 631-635 (2004).

36. TCHESNOKOVA V, APRIKIAN P, KISIELA D et al. Type 1 Fimbrial Adhesin FimH Elicits an Immune Response That Enhances Cell Adhesion of Escherichia coli. Infection \& Immunity, 79(10): 3895-3904 (2011).

37. WATTS RE, HANCOCK V, ONG CL et al. Escherichia coli Isolates Causing Asymptomatic Bacteriuria in Catheterized and Noncatheterized Individuals Possess Similar Virulence Properties. Journal of Clinical Microbiology, 48(7): 2449-2458(2010).

38. IBRAHEEM SA, KADHEM HA, HADEETHI SA, JABIR MS, GRIGORE R, POPA M, GHEORGHE I, FLORIN MD. Effects of silver nanoparticles on nosocomial Pseudomonas aeruginosa strains - an alternative approach for antimicrobial therapy. Rom Biotechnol Lett. 2019; 24(2): 286-293. DOI: 10.25083/rbl/24.2/286.293

39. JABERI AKH, COPACI E, MERNEA M, ALSHAMMARI RSS, CINTEZA LO, MIHAILESCU DF, STOIAN G. Synthesis and characterization of zeinchromium nanoparticles with antibacterial effects. Rom Biotechnol Lett. 2020; 25(3): 1628-1634. DOI: 10.25083/ $\mathrm{rbl} / 25.3 / 1628.1634$ 